Contents list available at Multidisciplinary Journal website Multidisciplinary Journal

Journal homepage: https://jurnal.unej.ac.id/index.php/multijournal

\title{
Daur Ulang Kombinasi Limbah Pertanian menjadi Kompos Berkualitas
}

\author{
Recycling Agricultural Waste Combinations Into Quality Compos \\ Moh Waisul Karomi ${ }^{1}$, Miswar ${ }^{1}$, Sugeng Winarso ${ }^{1 *}$ \\ ${ }^{1}$ Program Studi Agroteknologi, Fakultas Pertanian, Universitas Jember. Jl Kalimantan 37 Kampus Tegalboto Jember 68121 \\ *Email : winarsosugeng@unej.ac.id
}

\begin{abstract}
Waste Population in Indonesia According to the Ministry of Environment and Forestry (2015), the amount of landfill has reached 175,000 tonnes/day or the equivalent of 64 million tonnes/year. Utilization of the waste is used as solid organic fertilizer which can be applied to soil to increase crop production. The research used waste from cocopeat, banana fronds and maggot pupae. This study aims to determine the characteristics of solid organic fertilizers made from cocopeat waste, banana fronds and maggot pupae. In addition, there are materials, namely EM $M_{4}$ as microorganisms, molasses as a food source for microorganisms and water to regulate humidity during the composting process. Each parameter will be tested and compared with the minimum technical requirements for solid organic fertilizer contained in Permentan/SR.140/10/2011. The results showed that solid organic fertilizers made from cocopeat, banana fronds and maggot pupae were of the same quality as the minimum technical requirements, namely solid organic fertilizer. includes parameters $\mathrm{C} / \mathrm{N}$ ratio, $\mathrm{pH}$, water content and $\left(\mathrm{N}+\mathrm{P}_{2} \mathrm{O}_{5}+\mathrm{K}_{2} \mathrm{O}\right)$. The results of the best treatment research on sample $\mathrm{A}\left(100 \mathrm{ml} / \mathrm{EM}_{4}\right)$ meet the standards because above $4 \%$ the content of the nitrogen presentation is $4.72 \%$, phospor $\left(\mathrm{P}_{2} \mathrm{O}_{5}\right)$ is $4.40 \%$ while the potassium content is below the standard for making solid organic fertilizer with a percentage of 3.96\% for the variation of $100 \mathrm{ml} / \mathrm{EM}_{4}, 23.51 \%$ C-Organic has met the minimum standard, namely $15-25 \%$ and $C / N$ ratio of $4.98 \%$ is below the standard, which is below $5 \%$.
\end{abstract}

Keywords : Banana fronds, Cocopeat, EM4, Maggot pupae, Waste quality

\section{ABSTRAK}

Kepadatan limbah di Indonesia menurut Kementerian Lingkungan Hidup dan Kehutanan (2015) bahwa jumlah timbunan limbah di Indonesia telah mencapai 175.000 ton/hari atau setara 64 juta ton/tahun. Pemanfaatan limbah tersebut digunakan sebagai pupuk organik padat yang dapat diaplikasikan ketanah untuk meningkatkan produksi tanaman. Adapun dalam penelitian tersebut menggunakan limbah dari cocopeat, pelepah pisang dan pupa maggot. Penelitian ini bertujuan mengetahui karakteristik pupuk organik padat yang terbuat dari limbah cocopeat, pelepah pisang dan pupa maggot. Selain itu terdapat bahan yaitu $\mathrm{EM}_{4}$ sebagai mikroorganisme, molasses sebagai sumber makanan mikroorganisme dan air untuk mengatur kelembapan selama proses pengomposan. Setiap parameter diuji dan dibandingkan dengan persyaratan teknis minimum pupuk organik padat yang terkandung dalam Permentan/SR.140/10/2011. Hasil penelitian menunjukkan bahwa pupuk organik padat yang terbuat dari cocopeat, pelepah pisang dan pupa maggot memiliki kualitas yang sesuai dengan kualitas persyaratan teknis minimum yaitu pupuk organik padat Permentan 2011. meliputi parameter $\mathrm{C} / \mathrm{N}$ rasio, $\mathrm{pH}$, kadar air dan $\left(\mathrm{N}+\mathrm{P}_{2} 0_{5}+\mathrm{K}_{2} 0\right)$. Hasil penelitian perlakuan terbaik pada sampel $\mathrm{A}\left(100 \mathrm{ml} / \mathrm{EM}_{4}\right)$ memenuhi standar karena diatas $4 \%$ kandungan presentase nitrogen $4.72 \%$, phospor $\left(\mathrm{P}_{2} \mathrm{O}_{5}\right) 4.40 \%$ sedangkan kandungan kalium $\left(\mathrm{K}_{2} 0\right)$ di bawah standar pembuatan pupuk organik padat dengan presentase $3.96 \%$ untuk variasi $100 \mathrm{ml} / \mathrm{EM}_{4}$, C-Organik $23.51 \%$ sudah memenuhi standar minimum yaitu $15-25 \%$ dan $\mathrm{C} / \mathrm{N}$ rasio $4.98 \%$ dibawah standar dengan yaitu dibawah $5 \%$.

Kata Kunci : Cocopeat, EM, Pelepah Pisang, Pupa Maggot, Teknologi Limbah

\section{Pendahuluan}

Tanah merupakan media tumbuh tanaman yang mempunyai kandungan hara yang cukup untuk menunjang proses pertumbuhan tanaman sampai berproduksi. Ketersediaan hara dalam tanah sangat dipengaruhi oleh adanya bahan organik. Bahan organik merupakan bahan penting dalam menciptakan kesuburan tanah. Secara garis besar, bahan organik memperbaiki sifat-sifat tanah meliputi sifat fisik, kimia dan biologi tanah [1]. Menurut Kementerian Lingkungan Hidup dan Kehutanan [2] mengungkapkan 
bahwa jumlah timbunan limbah di Indonesia telah mencapai 175.000 ton/hari atau setara 64 juta ton/tahun.

Cocopeat merupakan hasil dari sabut kelapa bagian yang cukup besar dari buah kelapa, yaitu 35\% dari berat keseluruhan buah. Cocopeat merupakan limbah yang saat ini masih terbatas pemanfaatannya, yaitu sebagai media tanam [3]. Pelepah pisang merupakan limbah pertanian potensial yang belum banyak dimanfaatkan. Pelepah pisang memiliki berat jenis $0.29 \mathrm{~g} / \mathrm{cm}$ dengan ukuran panjang serat 4.20-5.46 mm dan kandungan lignin $33.51 \%$ [4]. Pemanfaatan limbah hasil dari biokonversi sampah menjadi bahan media tanam belakangan ini banyak ditemukan dari kegiatan daur ulang limbah organik dengan metode biokonversi. Menurut Newton [5] mendefinisikan biokonversi sebagai perombakan limbah organik menjadi sumber energi metan melalui proses fermentasi yang melibatkan organisme hidup. Umumnya organisme yang berperan dalam proses biokonversi ini adalah jamur, bakteri dan larva serangga. Biokonversi yang dilakukan oleh agen biokonversi yaitu larva BSF (Black Soldier Fly) atau yang biasa disebut juga maggot, ternyata mampu mengurangi limbah organik hingga 56\% dan sebagai agen biokonversi [6]. Pada penelitian tersebut juga menggunakan Effective Microorganisme $\left(\mathrm{EM}_{4}\right)$ sebagai teknologi pengolahan dalam mempercepat pembuatan pupuk organik padat yang dapat dianggap sebagai teknologi karena bertujuan untuk mempercepat proses fermentasi [7].

Kendala yang dialami petani yaitu beragam mulai kesuburan tanah dan penggunaan pupuk anorganik di Indonesia mampu meningkatkan hasil pertanian, namun tanpa disadari penggunaan pupuk anorganik secara terus menerus berdampak tidak baik bagi sifat fisik, kimia dan biologi tanah. Hal ini menyebabkan kemampuan tanah untuk mendukung ketersediaan air, hara dan kehidupan mikroorganisme dalam tanah menurun. Kondisi ini terjadi karena tingkat kesuburan dan bahan organik tanah mengalami penurunan, oleh karena itu jika tidak segera diatasi maka dalam jangka waktu tidak terlalu lama, lahan tersebut tidak dapat berproduksi secara optimal dan berkelanjutan. Solusi untuk mengatasi masalah ini yaitu mengurangi penggunaan pupuk anorganik dan menerapkan sistem pertanian organik [8]. Tujuan penelitian tersebut untuk mengetahui kandungan unsur hara pupuk organik padat dengan pemberian konsentrasi $\mathrm{EM}_{4}$ yang berbeda dengan menggunakan limbah cocopeat, pelepah pisang dan pupa maggot.

\section{Metode Penelitian}

\section{Waktu dan Tempat Penelitian}

Penelitian dilaksanakan pada bulan Agustus sampai Desember 2020 di Desa Wonojati Kecamatan Jenggawah Kabupaten Jember dan Laboratorium Kimia Tanah Fakultas Pertanian Universitas Jember.

\section{Alat dan Bahan Penelitian}

Alat dan bahan yang digunakan dalam penelitian diantaranya alat dan bahan yang umum digunakan dalam proses pembuatan pupuk organik padat. Alat yang digunakan diantaranya timbangan, karung plastik, parang, kamera, $\mathrm{pH}$ meter, thermometer, hygrometer, gelas ukur, alat untuk uji kandungan pupuk organik padat. Bahan yang diperlukan dalam penelitian yaitu limbah dari cocopeat, pelepah pisang, pupa maggot, $\mathrm{EM}_{4}$, molasses, dan air.

\section{Pembuatan Pupuk Organik Padat}

Menimbang bahan yang digunakan antara lain limbah cocopeat sebanyak $500 \mathrm{~g}$ dicampur dengan pelepah pisang yang telah dicacah dengan berukuran $<2 \mathrm{~cm}$ sebanyak $500 \mathrm{~g}$ dan ditambahkan pupa maggot $500 \mathrm{~g}$ kemudian ditambahakan dengan $\mathrm{EM}_{4}$ sesuai perlakuan, molasses $50 \mathrm{ml}$ dan air $1000 \mathrm{cc}$. Setelah itu dimasukkan kedalam plastik dan ditambahkan dengan $\mathrm{EM}_{4}$ dan molase yang sudah tercampur air dan diaduk hingga merata sehingga pupuk kondisi kapasitas lapang yaitu apabila adonan pupuk organik padat digenggam tidak mengeluarkan air dan apabila dilepas tidak hancur atau pecah. Fermentasi pupuk organik padat selama $<30$ hari [9]. Proses fermentasi yang digunakan yaitu anaerob secara terkendali.

Rancangan Percobaan

Tabel 1. Variabel Komposisi Pupuk Organik Padat

\begin{tabular}{ccccccc}
\hline & \multirow{2}{*}{$\begin{array}{c}\mathrm{EM}_{4} \\
\text { Variasi }\end{array}$} & $\begin{array}{c}\text { Molasses } \\
(\mathrm{cc})\end{array}$ & $(\mathrm{cc})$ & $\begin{array}{c}\text { Air } \\
(\mathrm{cc})\end{array}$ & \multicolumn{3}{c}{$\begin{array}{c}\text { Perbandingan } \\
\text { Limbah }(\mathrm{g})\end{array}$} \\
\cline { 5 - 7 } & & & & PP & CP & PM \\
\hline $\mathrm{A}$ & 100 & 50 & 1000 & 500 & 500 & 500 \\
$\mathrm{~B}$ & 300 & 50 & 1000 & 500 & 500 & 500 \\
$\mathrm{C}$ & 500 & 50 & 1000 & 500 & 500 & 500 \\
$\mathrm{D}$ & 700 & 50 & 1000 & 500 & 500 & 500 \\
\hline
\end{tabular}

Keterangan:

$\begin{array}{lll}\text { 1. } & \text { PP } & \text { (Pelepah Pisang) } \\ \text { 2. } & \text { CP } & \text { (Cocopeat) } \\ \text { 3. } & \text { PM } & \text { (Pupa Maggot) }\end{array}$

\section{Metode Analisis}

Analisis dilakukan secara kualitatif yaitu $\mathrm{pH}$, kadar air, $\mathrm{N},\left(\mathrm{P}_{2} \mathrm{O}_{5}\right),\left(\mathrm{K}_{2} \mathrm{O}\right)$, dan $\mathrm{C} / \mathrm{N}$ ratio. Pengamatan $\mathrm{pH}$ dilakukan menggunakan $\mathrm{pH}$ meter setiap tujuh hari sekali [10]. Kadar air menggunakan metode gravimetric dengan menimbang $10 \mathrm{~g}$ sampel kemudian dipanaskan pada suhu $105^{\circ} \mathrm{C}$ selama 24 jam [11]. Analisis N-Total dengan metode khajedhal [12]. Pengujian $\left(\mathrm{P}_{2} \mathrm{O}_{5}\right)$ [13] uji phospor $\left(\mathrm{P}_{2} \mathrm{O}_{5}\right)$ dilakukan dengan cara metode olsen. Pengujian kalium $\left(\mathrm{K}_{2} \mathrm{O}\right)$ [14] sampel ditimbang sebanyak 0,5 g, kemudian dilakukan proses pengabuan dengan penambahan $\mathrm{H}_{2} \mathrm{SO}_{4}$ pekat dan $\mathrm{HNO}_{3}$ pekat. Pengukuran rasio $\mathrm{C} / \mathrm{N}$ dilakukan dengan menghitung perbandingan nilai total C-organik dan $\mathrm{N}$ Total yang diperoleh dari data hasil analisis dilakukan diakhir pengamatan setelah $<30$ hari [11] 


\section{Hasil dan Pembahasan}

\section{Pengamatan Visual Pupuk Organik Padat}

Limbah organik yang yang digunakan yaitu limbah cocopeat, pelepah pisang dan pupa maggot didekomposisi dengan menggunakan konsentrasi $\mathrm{EM}_{4}$ yang berbeda $100,300,500$ dan $700 \mathrm{ml} / \mathrm{EM}_{4}$ dengan penambahan molasses setiap perlakuan $50 \mathrm{ml}$ dan air 1000 cc. Data hasil pengamatan visual pupuk organik padat dapat dilihat pada Tabel 2 berikut.

Tabel 2. Pengamatan Visual Pupuk Organik Padat Berbahan Limbah Cocopeat, Pelepah Pisang dan PupaMaggot

\begin{tabular}{|c|c|c|c|c|}
\hline \multirow{2}{*}{$\begin{array}{c}\text { Kouseut } \\
\text { rasi } \\
\text { EM-4 }\end{array}$} & \multirow{2}{*}{$\begin{array}{c}\text { Lama } \\
\text { Fermeatsii }\end{array}$} & \multicolumn{3}{|c|}{ Pezgamatau } \\
\hline & & Warma & Tekstur & Aroma \\
\hline $100 \mathrm{ml}$ & \multirow{4}{*}{$\begin{array}{l}\text { Minggn } \\
\text { Per:zma }\end{array}$} & $\begin{array}{c}\text { Oramg: } \\
\text { Xamerahm }\end{array}$ & M:szgzumpal & Tilak Ads Aroma \\
\hline $300 \mathrm{ml}$ & & $\begin{array}{c}\text { Oramg: } \\
\text { Xamerahm }\end{array}$ & Mexggumpal & Tilak Ada Aroma \\
\hline $500 \mathrm{ml}$ & & $\begin{array}{c}\text { Orang: } \\
\text { Kolitaman }\end{array}$ & Mexgzumpal & Tiluk Ads Aroma \\
\hline $700 \mathrm{ml}$ & & $\begin{array}{c}\text { Orang: } \\
\text { Xolitaman } \\
\end{array}$ & Menggumpal & Tidak Ads Aroma \\
\hline $100 \mathrm{ml}$ & \multirow{4}{*}{$\begin{array}{l}\text { Minggu } \\
\text { Kodua }\end{array}$} & $\begin{array}{c}\text { Coilat } \\
\text { Xomeraham }\end{array}$ & $\begin{array}{c}\text { Ramzin } \\
\text { Monggumpal }\end{array}$ & $\begin{array}{c}\text { Aroma Sadikit } \\
\text { Margangat } \\
\text { Molasses Den } \\
\text { Amoniz }\end{array}$ \\
\hline $300 \mathrm{ml}$ & & $\begin{array}{c}\text { Coklat } \\
\text { Xsmeraham }\end{array}$ & $\begin{array}{l}\text { Ramsh Sodiket } \\
\text { Maxggumpal }\end{array}$ & $\begin{array}{l}\text { Aroma Sodikit } \\
\text { Mosyamgat } \\
\text { Molasses Asam }\end{array}$ \\
\hline $500 \mathrm{ml}$ & & $\begin{array}{c}\text { Coislat } \\
\text { Kolitamas }\end{array}$ & $\begin{array}{c}\text { Ramin } \\
\text { Maxgzumpal }\end{array}$ & $\begin{array}{c}\text { Arcma Sadiktt } \\
\text { Momyengat } \\
\text { Molasses }\end{array}$ \\
\hline $700 \mathrm{ml}$ & & $\begin{array}{c}\text { Coiklat } \\
\text { Kolitaman }\end{array}$ & $\begin{array}{l}\text { Remsih Agzk } \\
\text { Moxgzumpal }\end{array}$ & $\begin{array}{c}\text { Arouza Manyamg2 } \\
\text { Aswm }\end{array}$ \\
\hline $100 \mathrm{ml}$ & \multirow{4}{*}{$\begin{array}{l}\text { Minggu } \\
\text { Kotigz }\end{array}$} & $\begin{array}{c}\text { Hitam } \\
\text { Kacoklatan } \\
\end{array}$ & $\begin{array}{c}\text { Ramì } \\
\text { Mamzgumpal } \\
\end{array}$ & Aroma Molasses \\
\hline $300 \mathrm{ml}$ & & $\begin{array}{c}\text { Hitam } \\
\text { Kacoilatan } \\
\end{array}$ & $\begin{array}{l}\text { Ramah Sodikit } \\
\text { Mloxgrumpal }\end{array}$ & Aroma Molasses \\
\hline $500 \mathrm{ml}$ & & $\begin{array}{c}\text { Hitam Agak } \\
\text { Pokat }\end{array}$ & $\begin{array}{l}\text { Romin Sodikit } \\
\text { Masagumpal }\end{array}$ & Aroma Mrolasses \\
\hline $700 \mathrm{ml}$ & & $\begin{array}{c}\text { Hitam Agat } \\
\text { Pokat }\end{array}$ & $\begin{array}{l}\text { Romih Sodikit } \\
\text { Manzrumpal }\end{array}$ & Aroma Mrolasses \\
\hline $100 \mathrm{ml}$ & \multirow{4}{*}{$\begin{array}{l}\text { Minggu } \\
\text { Reampat }\end{array}$} & Hitam & Rงmนh & Tiduk Ads Aroma \\
\hline $300 \mathrm{ml}$ & & Hitam & Rsm2 & Sodikit Aram \\
\hline $500 \mathrm{ml}$ & & Hitam & $\begin{array}{l}\text { Ramsh Sodikit } \\
\text { Manzrumpal }\end{array}$ & Tiluk Ads Aroma \\
\hline $700 \mathrm{ml}$ & & Hitam & $\begin{array}{l}\text { Romin Sodikt: } \\
\text { Mongzumpal }\end{array}$ & Tidak Ads Aroma \\
\hline
\end{tabular}

Tabel 2 menunjukkan bahwa konsentrasi $\mathrm{EM}_{4}$ $100 \mathrm{ml}$ lebih baik dari konsentrasi lainnya dalam hal lama fermentasi, warna, ukuran partikel, dan keremahan pupuk organik. Pengamatan visual dilakukan setiap minggu selama 30 hari, adapun indikator pengamatan visual setiap minggu berupa warna, tekstur dan aroma. Pengamatan warna terdapat perlakuan perubahan warna setiap minggunya, minggu pertama warna pupuk organik padat berwana orange kemerahan hal ini dikarenakan warna dari dasar molasses dan $\mathrm{EM}_{4}$ dan pembusukan pelepah pisang yang berwarna orange. Pada minggu kedua peningkatan warna berubah menjadi coklat kemerahan pada perlakuan 100 dan $300 \mathrm{ml} / \mathrm{EM}_{4}$, sedangkan pada perlakuan 500 dan $700 \mathrm{ml} / \mathrm{EM}_{4}$ mengalami perubahan warna menjadi coklat kehitaman. Hal ini menunjukkan bahwa proses dekomposisi secara anaerob secara terkendali berjalan dengan baik. Minggu ketiga dan keempat pada umumnya limbah yang difermetasi berubah warna hitam akan tetapi dikonsentrasi 500 dan $700 \mathrm{ml} / \mathrm{EM}_{4}$ warna hitamnya lebih pekat hal ini karena kandungan konsentrasi $\mathrm{EM}_{4}$ lebih tinggi. Kriteria pupuk organik padat yaitu berwarna hitam seperti tanah.
Pengamatan tekstur dilakukan setiap minggu dengan cara mengamati secara visual untuk mengetahui tingkat keremahaman pupuk organik, adapun indikator tingkat kematangan pupuk organik ketika dekomposisi mengalami perubahan dari minggu pertama hingga minggu terakhir. Pengamatan minggu pertama tekstur masih basah dan menggumpal, pada minggu kedua tesktur remah menggumpal pada konsentrasi 100 dan $500 \mathrm{ml} / \mathrm{EM}_{4}$ sedangkan pada konsentrasi 300 dan 700 $\mathrm{ml} / \mathrm{EM}_{4}$ remah sedikit menggumpal. Pengamatan minggu ketiga dan keempat pada umumnya remah, remah sedikit menggumpal, pada konsentrasi 100 dan $300 \mathrm{ml} / \mathrm{EM}_{4}$ kondisi fisik bentuk pupuk organik padat remah.

Aroma merupakan salah satu indikator sebagai parameter keberhasilan pembuatan kompos dengan ditandai diakhir pengamatan dihari ke-30 aroma sudah mulai berkurang dan tidak ada. Pengamatan minggu pertama dan minggu kedua pada perlakuan 100 $\mathrm{ml} / \mathrm{EM}_{4}$ beraroma sedikit menyengat molasses dan amonia sedangkan pada $300 \mathrm{ml} / \mathrm{EM}_{4}$ beraroma sedikit menyengat molasses asam. Pada perlakuan 500 dan $700 \mathrm{ml} / \mathrm{EM}_{4}$ cenderung lebih beraroma asam. Minggu ketiga aroma sudah berkurang hanya beraroma molasses dan minggu keempat mulai tidak ada aroma, indikitor matang yaitu ditandai dengan tidak ada aroma atau berbau tanah.

\section{Kadar Air}

Analisa pengamatan kadar air dilakukan pada akhir pengamatan setelah 30 hari dekomposisi dengan menggunakan oven kadar air. Hasil analisa ditunjukkan pada gambar 2 .

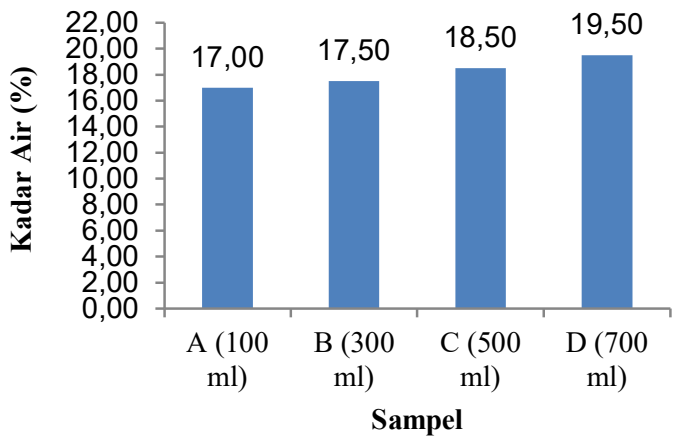

Gambar 1. Pengaruh $\mathrm{EM}_{4}$ terhadap kadar air

Kandungan tertinggi C-Organik pada variasi $\mathrm{EM}_{4} 100 \mathrm{ml}$ yaitu $23.51 \%$ sedangkan variasi 300 $\mathrm{ml} / \mathrm{EM}_{4} \quad 19.43 \%$ dan variasi $500,700 \mathrm{ml} / \mathrm{EM}_{4}$ berkisar $16 \%$. Hal ini karenakan semakin tingginya mikroba pengurai ketika dekomposisi akan tetapi jumlah sumber makanan mikroba (molasses) sedikit maka proses dekomposisi mengalami keterlambatan sehingga bahan organik yang terkandung rendah.

Kadar air sangat berpengaruh terhadap lamanya dekomposisi atau penguraian bahan-bahan organik karena kadar air dalam kompos berpengaruh pada reaksi biologis mikrooganisme dalam mengurai bahan organic [15]. Kandungan kadar air dibawah 30\% dalam bobot segar reaksi biologis dalam tumpukan kompos 
menjadi lambat. Berdasarkan gambar 1 kadar air paling tinggi pada konsentrasi $700 \mathrm{ml}^{-\mathrm{EM}_{4}}$ yaitu hampir mendekati $20 \%$ sedangkan terendah pada konsentrasi $100 \mathrm{ml} / \mathrm{EM}_{4}$ dengan kadar $17 \%$. Pada kadar air yang terlalu tinggi ruang antara partikel dari bahan menjadi penuh air, sehingga mencegah gerakan udara dalam tumpukan.

Kadar air yang optimum dari bahan pupuk organik adalah 50-60\% ketika dekomposisi. Kandungan kadar air pengomposan yang ideal tergantung dari jenis bahan organik yang digunakan ataupun jenis bahan organik yang paling banyak terdapat campuran. Kadar air memiliki hubungan erat dengan tingkat kelembapan sehingga kadar air yang rendah kelembapan juga rendah sedangkan jika kadar air tinggi maka kelembapan juga tinggi, hal ini dikarenakan adanya jumlah kadar air yang tinggi dikarenakan bahan organik yang digunakan [16]. Berdasarkan Permentan [17] kadar air yang ideal yaitu berkisar antara $15-25 \%$ di akhir pengamatan. Sedangkan ketika proses dekomposisi kadar air yang ideal $40-60 \%$ maka mikroorganisme pengurai akan bekerja optimal [18].

\section{pH}

Analisa pengamatan $\mathrm{pH}$ dilakukan pada setiap minggu sekali hingga pengamatan terakhir 30 hari dengan menggunakan $\mathrm{pH}$ meter. Hasil analisa ditunjukkan pada grafik 1 . Proses pengomposan sendiri akan menyebabkan perubahan pada bahan organik dan $\mathrm{pH}$ bahan itu sendiri. Sebagai contoh, proses pelepasan asam, secara temporer atau lokal, akan menyebabkan penurunan $\mathrm{pH}$ (pengasaman), sedangkan produksi amonia dari senyawa-senyawa yang mengandung nitrogen akan meningkatkan $\mathrm{pH}$ pada fase-fase awal pengomposan. $\mathrm{pH}$ kompos yang sudah matang biasanya mendekati netral yaitu 7 .

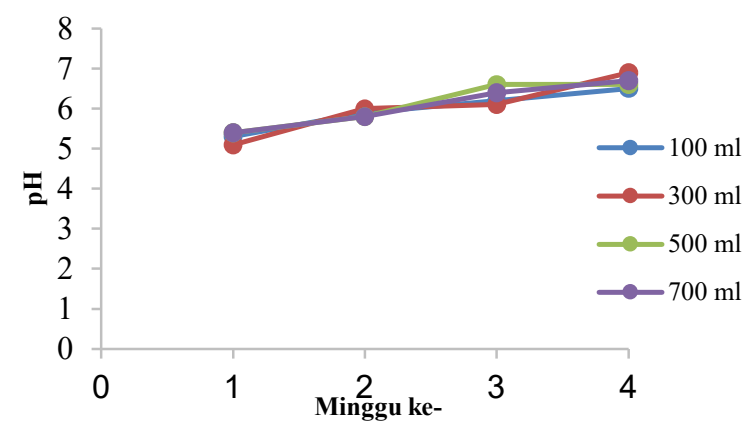

Gambar 2. Perubahan $\mathrm{pH}$ dengan Penambahan $\mathrm{EM}_{4}$ setiap minggu

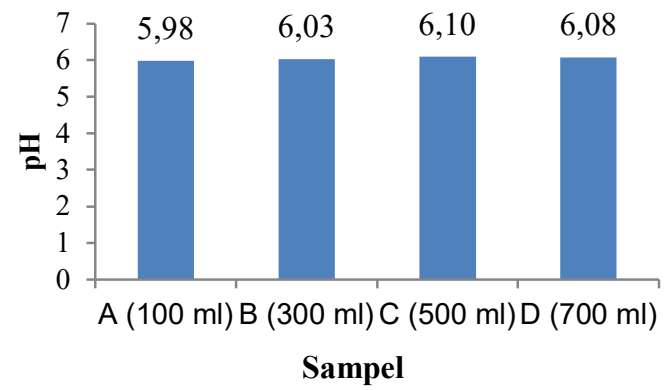

Gambar 3. Pengaruh $\mathrm{EM}_{4}$ Terhadap pH

Berdasarkan gambar 2 mengenai $\mathrm{pH}$ yaitu $\mathrm{pH}$ awal pengomposan dengan rataan 5.5 dan diakhir pengamatan di hari $30 \mathrm{pH}$ dengan rataan bisa mencapai 6.7 adanya perubahan $\mathrm{pH}$ menunjukkan terjadinya proses biodegradasi bagan organik (Gambar 2). Nilai $\mathrm{pH}$ pada awal proses degradasi anaerob secara terkendali akan meningkat, kemudian menurun. Peningkatan $\mathrm{pH}$ terjadi saat proses hidrolisis dimana $\mathrm{H}^{+}$digunakan untuk mengkatalisis reaksi pemutusan ikatan pad polisakarida, lipid dan protein [19]. Peningkatan $\mathrm{pH}$ menunjukkan adanya kegiatan mikroorganisme yang merugikan bahan organik seperti karbonhidrat yang diuraikan menjadi glukosa [20]. Kemudian terjadi asidogenenisis dan asetogenesis. Tahap asidogenesis dilakukan oleh berbagai kelompok mikroorganisme, yang mayoritas adalah mikroorganisme obligat anaerob dan anerob fakultatif. Selanjutnya $\mathrm{pH}$ mengalami peningkatan karena asam organik diuraikan menjadi metana dan karbodioksida. Namun pada penelitian ini nilai $\mathrm{pH}$ mengalami peningkatan dari hari pengamatan minggu pertama hingga keempat hal ini disebabkan karena proses yang terjadi di dalam reaktor sudah memasuki tahap penguraian asam organik, penguraian asam organik mulai terjadi setelah berlangsung lebih dari 2 hari [21]. Namun demikian, $\mathrm{pH}$ kompos yang ideal berdasarkan standar pembuatan pupuk organik padat yaitu 4-9[17]. Perlakuan $\mathrm{EM}_{4}$ yang lebih banyak menyebabkan nilai $\mathrm{pH}$ yang lebih besar hal ini dikarenakan sifat basa yang didapat dari $\mathrm{EM}_{4}$ menyebabkan bakteri tidak aktif dan kekurangan makanan sehingga sifatnya lebih basa.

\section{Kandungan $\mathrm{N}, \mathrm{P}_{2} \mathrm{O}_{5}, \mathrm{~K}_{2} \mathrm{O}$, dan $\mathrm{C} / \mathrm{N}$ ratio}

Penentuan kadar nitrogen pada pupuk organik padat hasil fermentasi dianalisis dengan metode makro khajedhal. Pengukuran kuantitatif kadar fosfor pada pupuk organik padat hasil fermentasi dianalisis dengan metode spektro fotometer UV-Vis yang membentuk molibdo fosfatvanadat. Sementara itu penentuan kadar kalium menggunakan metode spektrofotometer serapan atom (SSA). Hasil pengujian kandungan hara $\mathrm{N}$, $\left(\mathrm{P}_{2} \mathrm{O}_{5}\right),\left(\mathrm{K}_{2} \mathrm{O}\right)$ dan $\mathrm{C} / \mathrm{N}$ Ratio pada pupuk organik padat dari bahan limbah pelepah pisang, cocopeat dan pupa maggot dengan penambahan berbagai variasi $\mathrm{EM}_{4}$ disajikan pada Tabel 3. 


\begin{tabular}{|c|c|c|c|c|c|}
\hline $\begin{array}{c}\text { Variasi } \\
\text { EM4 }\end{array}$ & $\begin{array}{l}\mathrm{N} \\
(\%)\end{array}$ & $\begin{array}{l}\mathrm{P}_{2} \mathrm{O}_{5} \\
(\%)\end{array}$ & $\begin{array}{l}\mathrm{K}_{2} \mathrm{O} \\
(\%)\end{array}$ & $\begin{array}{c}\text { C-Organik } \\
(\%)\end{array}$ & $\begin{array}{c}\mathrm{C} / \mathrm{N} \\
\text { Ratio } \\
\end{array}$ \\
\hline $\begin{array}{c}\mathrm{A}(100 \\
\mathrm{ml})\end{array}$ & 4,72 & 4,40 & 3,96 & 23,51 & 4,98 \\
\hline $\begin{array}{c}\mathrm{B}(300 \\
\mathrm{ml})\end{array}$ & 4,07 & 4,08 & 3,57 & 19,43 & 4,77 \\
\hline $\begin{array}{c}\mathrm{C}(500 \\
\mathrm{ml})\end{array}$ & 3,78 & 3,30 & 2,87 & 16,18 & 4,28 \\
\hline $\begin{array}{c}\mathrm{D}(700 \\
\mathrm{ml})\end{array}$ & 3,48 & 3,64 & 3,20 & 16,30 & 4,69 \\
\hline
\end{tabular}

Formulasi kompos dari limbah cocopeat, pelepah pisang dan pupa maggot dengan penambahan perlakuan $\mathrm{EM}_{4}$ yaitu 100, 300, 500, $700 \mathrm{ml} / \mathrm{EM}_{4}$ dan molasses $50 \mathrm{ml}$, dihasilkan perlakuan terbaik pada perlakuan dengan penambahan $100 \mathrm{ml} / \mathrm{EM}_{4}$ dengan kandungan nitrogen $4.72 \%$, phospor $\left(\mathrm{P}_{2} \mathrm{O}_{5}\right) 4.40 \%$, kalium $\left(\mathrm{K}_{2} \mathrm{O}\right) \quad 3.96 \%$ dan C-Organik $23.51 \%$. Sedangkan pada perlakuan $300 \mathrm{ml} / \mathrm{EM}_{4}$ mendekati standar minimum yaitu 4\% untuk nitrogen 4.07\%, phosphor $\left(\mathrm{P}_{2} \mathrm{O}_{5}\right) 4.08 \%$, kalium $\left(\mathrm{K}_{2} \mathrm{O}\right) 3.57 \%$ dan $\mathrm{C}$ Organik $19.43 \%$. Adapun standar minimum C-Organik yaitu $15-20 \%$ [17]. Pada perlakuan 500 dan 700 $\mathrm{ml} / \mathrm{EM}_{4}$ tidak mencapai standar minimum SNI pembuatan pupuk organik karena dibawah $4 \%$ hal ini dikarenakan semakin tinggi mikroba yang ditambahkan akan meningkatkan kecepatan dekomposisi sehingga sumber bahan makan (molasses) tidak seimbang dengan presentase jumlah mikroba dan proses dekomposisi tidak terdekomposisi semua bahan organik limbah yang digunakan dan menyebakan tingginya kadar air [22].

Menurut Widarti [15] pada proses pengomposan nilai rasio $\mathrm{C} / \mathrm{N}$ mengalami penurunan disebabkan oleh terjadinya penurunan jumlah karbon yang dipakai sebagai sumber energi mikroba untuk mendekomposisi material organik. Selama proses penguraian terjadi penurunan kadar C-Organik dan peningkatan kadar $\mathrm{N}$ total. Menurunnya kadar $\mathrm{C}$ disebabkan karena digunakan oleh mikroorganisme sebagai sumber energi. Meningkatnya kadar N kemungkinan disebabkan karena terjadi mineralisasi N-Organik menjadi N-mineral [23]. Menurut Djuarnani dalam Purnomo dkk [24] bahwa salah satu aspek penting dalam keseimbangan unsur hara total adalah rasio $\mathrm{C} / \mathrm{N}$. Rasio $\mathrm{C} / \mathrm{N}$ bahan organik adalah perbandingan antara banyaknya kandungan unsur karbon (C) terhadap banyaknya kandungan unsur nitrogen $(\mathrm{N})$ yang ada pada suatu bahan organik. Mikroorganisme membutuhkan $\mathrm{C}$ dan $\mathrm{N}$ untuk aktivitas hidupnya. Jika rasio $\mathrm{C} / \mathrm{N}$ tinggi, aktivitas biologi mikroorganisme pun akan berkurang. Diperlukan beberapa siklus mikroorganisme untuk mendegradasi kompos, sehingga diperlukan waktu yang lama dan dihasilkan mutu yang lebih rendah. Kemudian jika rasio $\mathrm{C} / \mathrm{N}$ terlalu rendah, kelebihan $\mathrm{N}$ yang tidak dipakai oleh mikroorganisme tidak dapat diasimilasi dan akan hilang melalui volatisasi sebagai amoniak atau terdenitrifikasi. Adapun faktor dalam proses dekomposer yang dilakukan jumlah $\mathrm{EM}_{4}$ juga memperngaruhi hasil akhir pengujian di laboratorium, karena $\mathrm{EM}_{4}$ mengandung mikroba heterotropik yang dapat mengikat [25].

Semakin banyak jumlah $\mathrm{EM}_{4}$ yang diberikan maka rasio $\mathrm{C} / \mathrm{N}$ yang didapat akan semakin kecil [25]. Hal ini disebabkan jumlah karena semakin banyak jumlah mikroba yang terdapat dalam sampel maka senyawa organik yang terdapat didalam sampel akan terkedomposisi semakin banyak. $\mathrm{C} / \mathrm{N}$ Rasio yang paling optimum terdapat pada sampel dengan penambahan $\mathrm{EM}_{4}$ sebanyak $30 \mathrm{ml}$ dan molase $15 \mathrm{ml}$ pada $80 \mathrm{~g}$ limbah padat, yang berarti supplay makanan mikroorganisme harus seimbang dengan jumlah makan yang tersedia (molasses) sehingga mikroorganisme dapat bertahan hidup dan menjalankan peranya untuk mendekomposisi limbah. Pada C/N Ratio pada 100 $\mathrm{ml} \mathrm{EM}_{4}$ lebih tinggi dari perlakuan lainya disebabkan nilai C-Organik dan $\mathrm{N}$ total tinggi, selain itu nilai nitrogen, phospor $\left(\mathrm{P}_{2} \mathrm{O}_{5}\right)$, dan kalium $\left(\mathrm{K}_{2} \mathrm{O}\right)$ sesuai standart SNI 2011. Sedangkan perlakuan $500 \mathrm{ml} / \mathrm{EM}_{4}$ nilai $\mathrm{C} / \mathrm{N}$ Ratio rendah yang mampu mendegradasi limbah dengan cepat. Namun nilai nitrogen, phospor $\left(\mathrm{P}_{2} \mathrm{O}_{5}\right)$, dan kalium $\left(\mathrm{K}_{2} \mathrm{O}\right)$ di bawah standar SNI. Hubungan interaksi dari ketiga limbah cocopeat, pelepah pisang dan pupa maggot dengan perlakuan 100 $\mathrm{ml} / \mathrm{EM}_{4}$ yaitu kandungan nitrogen $4.72 \%$, phospor $\left(\mathrm{P}_{2} \mathrm{O}_{5}\right) \quad 4.40 \%$ dan kalium $\left(\mathrm{K}_{2} \mathrm{O}\right) \quad 3.96 \%$ sedangkan gabungan dari hasil analisa kandungan nitrogen, phospor $\left(\mathrm{P}_{2} \mathrm{O}_{5}\right)$, dan kalium $\left(\mathrm{K}_{2} \mathrm{O}\right)$ berbahan limbah cocopeat, pelepah pisang dan pupa maggot yaitu nitrogen $8.52 \%$, phospor $\left(\mathrm{P}_{2} \mathrm{O}_{5}\right) 3.87 \%$ dan kalium $\left(\mathrm{K}_{2} \mathrm{O}\right) 3.996 \%$ dari per $100 \mathrm{~g}$ (Hasil Analisis Politeknik Negeri Jember, 2019). Hal tersebut mengalami penurunan pada uji kandungan nitrogen, phospor $\left(\mathrm{P}_{2} \mathrm{O}_{5}\right)$, dan kalium $\left(\mathrm{K}_{2} \mathrm{O}\right)$ konsentrasi $100 \mathrm{ml} / \mathrm{EM}_{4}$ dengan dibandingkan studi literatur. Hal tersebut banyak berbagai faktor diantaranya, lama fermentasi, ukuran bahan, konsentrasi $\mathrm{EM}_{4}$ dan molase.

$\mathrm{C} / \mathrm{N}$ Ratio merupakan faktor terpenting dalam pengomposan. Proses pengomposan akan berjalan baik jika $\mathrm{C} / \mathrm{N}$ Ratio bahan organik yang dikomposkan sekitar 25-35. Imbangan $\mathrm{C} / \mathrm{N}$ yang terlalu tinggi akan menyebabkan proses pengomposan berlangsung lambat. Keadaan ini disebabkan mikroorganisme yang terlibat dalam proses pengomposan kekurangan nitrogen $(\mathrm{N})$. Sementara itu, imbangan yang terlalu rendah akan menyebabkan kehilangan nitrogen dalam bentuk amonia yang selanjutnya akan teroksidasi. Kecepatan dekomposisi bahan organik ditunjukkan oleh perubahan $\mathrm{C} / \mathrm{N}$ Ratio [26]. Adapun peraturan persyaratan minimal teknis pembuatan pupuk organik yang menyatakan bahwa kandungan C-Organik dalam pupuk organik padat yaitu minimal 15\% [17].

Manfaat $\mathrm{EM}_{4}$ [25] yaitu memperbaiki sifat fisika, kimia dan biologis tanah, menekan pertumbuhan bakteri patogen tanah, meningkatkan ketersediaan nutrisi dan senyawa organik tanah, meningkatkan mikroba indigenus yang menguntungkan, misalnya mycoriza, rhizobius, dan bakteri pelarut fosfat lainnya. Dari hasil rataan nilai kandungan phospor tertinggi pada konsentrasi 100 dan $300 \mathrm{ml} / \mathrm{EM}_{4}$ yaitu 4\% sedangkan kandungan phospor sedangkan konsentrasi 500 dan 700 $\mathrm{ml} / \mathrm{EM}_{4}$ berkisar antara $3.3 \%$. phospor merupakan 
unsur hara makro yang sangat penting untuk pertumbuhan dan perkembangan tanaman. Phosphor berperan dalam macam-macam metabolisme utama seperti karbohidrat, protein dan lemak [27]. Selain itu, phospor berguna sebagai bahan mentah untuk pembentukan protein, membantu asmilasi dan pernafasan serta mempercepat pembungaan, pemasakan biji, dan buah [28].

\section{Kesimpulan}

Berdasarkan hasil penelitian dapat disimpulkan bahwa perlakuan pada sampel A (100 $\left.\mathrm{ml} / \mathrm{EM}_{4}\right)$ memenuhi standar karena diatas $4 \%$ untuk kandungan nitrogen dan phospor dengan prenstasi nitrogen $4.72 \%$, phospor $\left(\mathrm{P}_{2} \mathrm{O}_{5}\right) 4.40 \%$ sedangkan kandungan kalium $\left(\mathrm{K}_{2} \mathrm{O}\right)$ di bawah standar pembuatan pupuk organik padat dengan presentase $3.96 \%$ untuk variasi 100 $\mathrm{ml} / \mathrm{EM}_{4}, \mathrm{C}$-Organik sudah memenuhi standar minimum yaitu $15-25 \%$ dan $\mathrm{C} / \mathrm{N}$ rasio dibawah standar dengan yaitu dibawah 5\%. Permentan SR.140/10/2011. Semakin banyak penambahan $\mathrm{EM}_{4}$ (Effective Microorganism) maka semakin kecil $\mathrm{C} / \mathrm{N}$ rasio yang didapat. Hasil dari variasi pemberian $\mathrm{EM}_{4}$ dengan 4 konsentrasi 100, 300, 500 dan $700 \mathrm{ml}^{-\mathrm{EM}_{4}}$ dapat simpulkan bahwa semakin banyak mikroba yang ditambahkan akan meningkatkan kecepatan dekomposisi sehingga sumber bahan panganya menjadi cepat menjadi pembatas. Dalam perlakuan terbaik dari penelitian tersebut yaitu penggunaan $\mathrm{EM}_{4}$ dengan konsentrasi $100 \quad \mathrm{ml} / \mathrm{EM}_{4}$ dengan molase yang digunakan $50 \mathrm{ml}$.

\section{Referensi}

[1] Dewi, Y.S., dan Tresnowati. 2012. Pengolahan sampah skala rumah tangga menggunakan metode composting. Jurnal Ilmiah Fakultas Teknik. 8(2): 35-48.

[2] Kementerian Lingkungan Hidup dan Kehutanan. 2015. Rangkaian harilingkungan hidup 2015-dialog penanganan sampah plastik. Tersedia pada: http://www.menlh.go.id.

[3] Mulyawan, M., Setyowati, E., Widjaja, A. 2015. Surfaktan sodium ligno sulfonat (SLS) dari debu sabut kelapa. Jurnal Teknik ITS, 4(1): 1-3.

[4] Syarifudin 2004. Pengaruh Konsentrasi Larutan dan Waktu Pemasakan Terhadap Rendemen dan Sifat Fisik Pupl Batang Pisang. Skripsi Fakultas Kehutanan. Yogyakarta Universitas Gajah Mada.

[5] Newton L, Sheppard C, Watson DW, Burtle G, Dove R. 2005. Using the black soldier fly, Hermetia illucens, as a value- added tool for the management of swine manure. Report for The Animal and Poultry waste Management Center. North Carolina. North Carolina State University Raleigh.

[6] Balitbangtan (BB Veteriner). 2016. Lalat Tentara Hitam Agen Biokonversi Sampah Organik Berprotein Tinggi. Diakses dari: http://www.litbang.pertanian.go.id/berita/on e/2557.

[7] Djuarnani, N dkk. 2005. Cara Cepat Membuat Kompos. Cetakan Pertama. AgroMedia.

[8] Pratiwi, I.G.A.P., Atmaja, I.W.D.A., Soniari, N.N. 2013. Analisis Kualitas Kompos Limbah Persawahan dengan Mol Sebagai Dekomposer. E-Jurnal Agroekoteknologi Tropika Vol. II-4: 195-203.

[9] Wijaksono dan R. Anggi. 2016. Pengaruh Lama Fermentasi pada Kualitas Pupuk Kandang Kambing. Agro Industri Perkebunan, 4(2):88-96.
[10] Agus. F. 2005. Petunjuk teknis Analisis Kimia Tanah Tanaman Air dan Pupuk. Balai Penelitian Tanah. Bogor.

[11] Kusuma, M. dan Angga. 2012. Pengaruh Variasi Kadar Air terhadap Laju Dekomposisi Kompos Sampah Organik di Kota Depok. Skripsi. Fakultas Teknik. Universitas Indonesia:Depok

[12] Balai Penelitian Tanah. 2005. Analisis Kimia Tanah, Tanaman, Air, dan Pupuk. Badan Penelitian dan Pengembangan Pertanian (DEPTAN). Bogor.

[13] Umaternate, Ghazaly R., J. Abidjulu., dan A.D.Wuntu. 2014. Uji Metode Olsen dan Bray dalam Menganalisis Kandungan Fosfat Tersedia pada Tanah Sawah di Desa Konarom Barat Kecamatan Dumoga Utara. Mipa Unsrat Online, 3(1):6-10.

[14] Indrawan, I. Made Ogik., G.A.B. Widana., dan M.V.Oviantari. 2016. Analisis Kadar N,P,K dalam Pupuk Kompos Produksi Tpa Jagaraga, Buleleng, 9(2):25-31.

[15] Widarti, B.N., Wardhini, W.K., Sarwono. 2015. Pengaruh rasio $\mathrm{C} / \mathrm{N}$ bahan baku pada pembuatan kompos dari kubis dan kulit pisang. Jurnal Integrasi Proses 5(2): 75-80.

[16] Pandebesie, E.S., Rayuanti, D. 2013. Pengaruh penambahan sekam pada proses pengomposan sampah domestik. Jurnal Lingkungan Tropis 6(1): 31-40.

[17] Kementrian Pertanian 2011. Peraturan Menteri Pertanian Nomer 70/Permentan/SR. 140/10/2011. Tentang Pupuk Organik, Pupuk Hayati dan Pembenah Tanah.

\{18] Sriharti., dan Salim, T. 2010. Pemanfaatan sampah tanam (rumput-rumputan) untuk pembuatan kompos Prosiding Seminar Nasional Teknik Kimia "Kejuangan" Pengembangan Teknologi Kimia untuk Pengolahan Sumber Daya Alam Indonesia, Yogyakarta, 26 Januari 2010. p.1-8.

[19] Chotimah, S. N. 2010. "Pembuatan Biogas dari Limbah Makanan dengan Variasi dan Suhu Substrat dalam Biodigester Anaerob". Universitas Negeri Sebelas Maret., Surakarta.

[20] Iswanto, W. Astono, Sunaryati. 2007. "Pengaruh Penguraian Sampah Terhadap Kualitas Air Ditinjau dari Perubahan Senyawa Organik Dan Nitrogen Dalam Reaktor Kontinyu Skala Laboratorium". Volume 4 No.1 (3).

[21] Husin. 2008. "Pengolahan Limbah Cair Industri Tahu Dengan Biofiltrasi Anaerob dalam Reaktor Fixed-Bed". Universitas Sumatera Utara, Medan.

[22] Suwatanti, P Widiyaningrum. 2017. Pemanfaatan MOL Limbah Sayur pada Proses Pembuatan Kompos. Jurusan Biologi, FMIPA, Universitas Negeri Semarang, Indonesia. Jurnal MIPA 40 (1) (2017): 1-6.

[23] Mulyadi, A., 2008, Karakteristik Kompos dari Bahan Tanaman Kaliandra, Jerami Padi, dan Sampah Sayuran, IPB Bogor.

[24] Purnomo, E. A., Sutrisno, E., Sumiyati, S. 2017. Pengaruh Variasi C/N Rasio Terhadap Produksi Kompos dan Kandungan Kalium (K), Pospat (P) dari Batang Pisang dengan Kombinasi Kotoran Sapi dalam Sistem Vermicomposting. Jurnal Teknik Lingkungan. Vol. 6, No. 2, Hal. 1-15.

[25] Ali, F., D. P. Utami, dan N. A. Komala. 2018. Pengaruh Penambahan $\mathrm{EM}_{4}$ dan Larutan Gula Pada Pembuatan Pupuk Kompos Dari Limbah Industri Crumb Rubber. Jurnal Teknik Kimia. 24(2):47-55.

[26] Simamora S, dan Salundik. 2006. Meningkatkan Kualitas Kompas. Jakarta: Agro Media Pustaka.

[27] Juanda, I. dan Nurdiana. 2011. Pengaruh Metode Dan Lama Fermentasi Terhadap Mutu Mikroorganisme Lokal. J. Floratek. 6:140-143.

[28] Roidah dan S. Ida. 2013. Manfaat Penggunaan Pupuk Organik Untuk Kesuburan Tanah. Jurnal Universitas Tulungagung BONOROWO. 1(1) : 30-42. 